\title{
Inequality and Spatial Convergence in the Mexico City Metropolitan Area, 1989-2010
}

\author{
Luis Quintana-Romero ${ }^{1, *}$, Jaime A. Prudencio-Vázquez ${ }^{1}$ and Carlos Salas Páez² \\ ${ }^{1}$ School of Higher Studies Acatlán (FES-Acatlán), National Autonomous University of Mexico (UNAM), \\ Mexico \\ ${ }^{2}$ Centre for Labour Economics and Trade Unionism (Cesit), Economics Institute,University of Campinas \\ (Unicamp), Brazil
}

\begin{abstract}
The analysis of inequality and polarization patterns between by regions of a national economy is central to ascertain their possibilities of future economic development. In this work we study such patterns in municipalities and boroughs of Mexico City Metropolitan Area (Zona Metropolitana de la Ciudad de Mexico, ZMCM). The evolution of inequality and polarization in this important area of Mexico is studied with new proposals of measurement using spatially conditioned indexes and through a dynamic transition analysis. The results confirm that the territorial inequality has grown among the municipalities and boroughs that integrate the ZMCM. Moreover, this phenomenon coincides with an increase of the polarization characterized by the formation of four subgroups or convergence clubs.
\end{abstract}

Keywords: Inequality, polarization, dynamic transition, Mexico City Metropolitan Area (ZMCM).

\section{INTRODUCTION}

The central region of Mexico, and particularly the Mexico City Metropolitan Area (Zona Metropolitana de la Ciudad de México, hereafter ZMCM), was the geographic heart of the Import Substitution Industrialization (ISI) process which was adopted in the forties as a model of development, and ended during the early eighties. Such process implied a hyperconcentrated albeit diversified production structure in the ZMCM (Unikel, Ruíz and Garza 1976).

During the ISI period, economic growth was closely associated with the domestic market and the dynamics of the national industry. Economic concentration spurred population concentration in the Federal District and the State of Mexico: in 1957, the share of the population in the ZMCM in the central region of the country was $57 \%$ (Pérez 2006).

Nevertheless, since the seventies this area has undergone a process of hollowing of its economic activity and a slightly diminishing population (Isaac and Quintana 2012), a real turning point in the dynamics of development that reflects major changes in the economic process and structure of this region (Chávez and Guadarrama 2004).

Trade opening, which started in the eighties, modified the production structure and its distribution in the territory. Industrial activities of the ZMCM lost

${ }^{*}$ Address correspondence to this author at the School of Higher Studies Acatlán (FES-Acatlán), National Autonomous University of Mexico (UNAM),

Programa de Investigación, Av. Alcanfores y Sn. Juan Totoltepec s/n, col. Sta.

Cruz Acatlán, cp.53150, Naucalpan, Edo. de México, México;

Tel: +5255 56231525; E-mail: luquinta@apolo.acatlan.unam.mx relevance to regions located in the north of the country, west and Gulf of Mexico (Connolly 1993), and there is a relative de-industrialization along with a loss of competitiveness of the industrial plant, and expressed by the decrease in its contribution to the national GDP and the loss of jobs and job precarization in industry (Pérez 2006).

The change in accumulation regime has been characterized as "an export-led, foreign investment based industrialization strategy and greater integration with the economy of the United States" (Valdivia 2008:7). This alteration in the accumulation regime did not result in higher rates of growth or a reduced inequality in the country. In this context, it is vital to know what has been the dynamics of the spatial disparities inside the ZMCM.

Few studies on the territorial inequality in the ZMCM attempt to go beyond the usual simple measurements such as the Gini index or some sort of convergence index. Among those few innovative studies we find, Borrayo and Castañeda (2011), who conducted a study of dynamic transition of the income level for Central Mexico region with information at the municipal level, covering the period 1988-2003. In that work the authors note three types of phenomena in the metropolitan area: persistence, mobility, and polarization in income levels.

Also, Valdivia (2008) studied the behavior of productivity for the Central Mexico region with disaggregation at the municipal level. Their results show that municipalities and boroughs from the region 
went from a unimodal distribution in 1998 to one with three modes in 2003, suggesting that the region maintains a process of polarization between rich and poor regions.

This paper presents a study of the inter-territorial spatial inequality for the municipalities in the ZMCM, extending the period of analysis in relation to previous studies and incorporating polarization and inequality measurements that are complementary to the dynamic transition analysis. We demonstrate that inequality has increased within municipalities and boroughs of the ZMCM in Mexico, and this phenomenon concurs with a rising polarization. We use an assorted set of indexes measuring income inequality and polarization. In fact, using a dynamic transition analysis, it is shown that such the polarization process is characterized by the formation of four sub-groups or convergence clubs.

In the period from 1989 to 2010 , we can separate at least three distinct subperiods, based on in the behavior of the calculated indices: from 1989 to 1995 , in which inequality describes an upward behavior; a second period, from 1995 to 2006, in which inequality continues to rise but a slower pace; and a third period, from 2006 to 2009 , where inequality is growing rapidly.

We construct two groups and show an increase of the polarity as by the end of the period polarization increased between 20 and $28 \%$. Three sub-periods can be distinguished: 1989-1995, in which polarity increases with oscillations; 1995-2006, where polarity unquestionably rose; and 2006-2010, where polarity grew rapidly.

Analysis of the shape of the distribution reveals that most municipalities and boroughs exhibited a per capita income lower than the average, even though there exist municipalities where the difference in the income level is up to 10 times the metropolitan area average. The number of municipalities and boroughs that have per capita income below the average rose through the period. A divergent pattern in the middle and upper income is clearly visible, and a strong persistence in low-income levels became evident, whereas no kind of global convergence among municipalities and boroughs of the ZMCM was found; instead we found local convergence processes or clubs.

The work is divided into six sections including this Introduction. The second section reviews theoretical aspects of economic growth and inequality. In the third section we discuss standard measures of inequality followed by an analysis of the external shape of the distribution and dynamic transition. In the in the fourth section we present some stylized facts on the evolution of per capita income of the ZMCM, while the results are analyzed and discussed in the fifth section, ending with some concluding remarks.

\section{THEORETICAL NOTES ON ECONOMIC GROWTH AND INEQUALITY}

Growth and inequality are intimately related phenomena; they appear at each scale of spatial analysis and with different intensities. The link between growth and inequality on a regional basis was first examined using the growth poles theory of Perroux (1950) and the proposals of a circular cumulative causation process of Gunnar Myrdal (1957). Nevertheless, the prevailing model used to discuss the territorial inequality has been the Solow (1956) growth model, which in its standard version is totally opposed to the "disequilibrium" arguments of Perroux and Myrdal.

For neoclassical economics, two economies or regions with a different degree of development will tend to converge over time and achieve the same level of per capita income (Barro 1991; Sala-i-Martin 1996; Rosende 2000; Sánchez 2009; Maier and Trippl 2009). Even if, from the neoclassical perspective, thousands of regressions have been estimated, the evidence is not conclusive. On the contrary, numerous empirical studies do not validate the convergence hypothesis at the regional level (Garnick 1990; Blanchard and Katz 1992; Carlino 1992; Mallick 1993; Crihfield and Panggabean 1995; Glaeser, Scheinkman and Shleifer 1995; Drennan 1996; Vohra 1996; Drennan and Lobo 1999).

Some more sophisticated versions have emerged that can relax some of the traditional neoclassical assumptions, by the incorporation of new variables into the standard production function and attempt to explain differentials in growth rates between distinct economies. This has been done by Robert Lucas (1988) and Romer (1990) using human capital theory, ${ }^{1}$ and by Krugman (1991) using the New Economy Geography considering imperfect markets, and the role of the agglomeration economies in economic development.

${ }^{1}$ Lucas and Romer's arguments are proved to be a consequence of accounting identities with no theory support (Felipe and McCombie 2015). 
One of the main critical contributions to the study of the processes of territorial inequality is the one that proposes the existence of convergence clubs, i.e., the clustering of inequality reduction processes in specific concentration poles (Ben-David 1994; Quah 1996a; Galor 1996). Quah's critique (Quah 1993; Quah 1996a; Quah 1996b; Quah 1997) points out that the empirical estimations of the convergence equations are a Galtontype fallacy as they do not consider the complete distribution of income among regions. For Quah, the dominant feature of the territorial dynamics of income between regions is persistence, immobility, and polarization.

This paper builds on the Quah's approach to analyze the complete distribution of per capita income using stochastic kernels.

\section{SPECIFIC MEASURES OF INEQUALITY, EXTERNAL SHAPE OF THE DISTRIBUTION AND DYNAMIC TRANSITION}

In order to quantify regional polarization, we can use three different sets of inequality indicators (Ezcurra and Rodriguez-Pose 2009); 1) standard measures of inequality, 2) a specific measure of polarization proposed by Esteban and Ray (1994) and 3) nonparametric methods to measure polarization: the external shape of the distribution and the distribution mobility.

\section{i. Specific Measures of Inequality}

The standard measures of dispersion are the prevalent method to capture inequality, they synthesize in a scalar, information on the behavior of the distribution of the variable (in this case, the measure of average per capita income). We will use the following four indexes:

- $\quad$ The coefficient of variation, $c$.

- $\quad$ Gini index, $G$.

- $\quad$ Generalized entropy measures, $G E(\theta)$.

- $\quad$ Atkinson indexes, $A(\varepsilon)$.

The coefficient of variation (c) is shown in expression (1):

$$
c=\frac{\sqrt{\sum_{i=1}^{n} p_{i}\left(x_{i}-\mu\right)^{2}}}{\mu}
$$

Where:

$\mu=\sum_{i=1}^{n} p_{i}$

$p_{i}=$ share of the population of a region $i$ in a given year

$x_{i}=$ measure of per capita income

The Gini index $(G)$ is the ratio of the area between the Lorenz curve and the line of equal distribution and can be written as shown in expression (2).

$G=\frac{\sum_{i=1}^{n} \sum_{i=1}^{n} p_{i} p_{j}\left|x_{i}-x_{j}\right|}{\mu}$

Generalized entropy measures, $G E(\theta)$, shown in expression (3), satisfy several properties that help to perform different decompositions on the total inequality.

$$
G E(\theta)=\left\{\begin{array}{c}
\sum_{i=1}^{n} p_{i} \ln \left(\frac{\mu}{x_{i}}\right) ; \theta=0 \\
\sum_{i=1}^{n} p i\left(\frac{x i}{\mu}\right) \ln \left(\frac{x i}{\mu}\right) ; \theta=1
\end{array}\right.
$$

Atkinson indexes, $A(\varepsilon)$, whose formula is shown in (4), come from a social welfare function and allow to quantify the welfare loss associated with the dispersion of income.

$$
A(\varepsilon)=\left\{\begin{array}{c}
1-\left[\sum_{i=1}^{n} p_{i}\left(\frac{x_{i}}{\mu}\right)^{1-\varepsilon}\right]^{\frac{1}{1-\varepsilon}} ; \varepsilon \neq 1 \\
1-\prod_{i=1}^{n}\left(\frac{x_{i}}{\mu}\right)^{p_{i}} ; \varepsilon=1
\end{array}\right.
$$

As remarked by Ezcurra and Rodríguez-Pose (2009) these formulations of standard inequality measures take into account the different sizes of territorial units. These four measures of inequality also satisfy the Lorenz dominance criteria

\section{ii. Specific Measure of Polarization}

We will use an index proposed by Esteban and Ray (1994) to estimate a measure of polarization between groups. The degree of polarization $\mathrm{P}^{\mathrm{ER}}$ of a distribution $f$ for a given number of groups - $m$ - is given by: 
$P^{E R}(f, \propto, p)=\sum_{j=1}^{m} \sum_{k=1}^{m} p_{j}^{1+\alpha} p_{k}\left|\mu_{j}-\mu_{k}\right|$

where:

$\mu_{j}=$ average per capita income of group j normalized by the sample mean

$\mu_{k}=$ average per capita income of group $\mathrm{k}$ normalized by the population share of group $\mathrm{k}$ in total sample

$\alpha \in[1,1.6]$ parameter reflecting the sensitivity to polarization

The groups are generated with the algorithm proposed by Davies and Shorrocks (1989), which makes possible to find the optimal partition of the series $\left(p^{*}\right)$ that minimizes the value of the Gini inside the groups so that the Esteban and Ray index in its generalized form is:

$P^{E G R}\left(f, \propto, p^{*}, \beta\right)=P^{E R}\left(f, \propto, p^{*}\right)-\beta\left[G(f)-G\left(p^{*}\right)\right]$

\section{iii. Non-Parametric Methods of Polarization}

Quah develops and implements an alternate methodology called dynamic transition approach whose advantage is that it does not assume any a priori probability distribution (Quah 1993) as frequently used models do assume. This approach allows the study of the evolution of the concentration of income around two or more mode points.

The pervasive method to identify the shape of the distribution is the smoothing kernels, whose density distribution function is:

$$
f(x)=\frac{1}{h} \sum_{i=1}^{n} p_{i} K\left(\frac{x-x_{i}}{h}\right)
$$

where:

$\mathrm{K}=$ Kernel function

$\mathrm{h}=$ smoothing parameter

$\mathrm{p}_{\mathrm{i}}=$ share of the population of the region $\mathrm{i}$

The kernel estimation method described is static and does not consider the possible movements experienced by a region over time. Therefore, it is necessary to approach the inside distribution dynamics. We once more abide by Ezcurra and Rodríguez-Pose
(2009), who collect contributions from the work of Quah on inside distribution mobility.

The distribution of per capita income in a set of regions for a given period $\mathrm{t}$ has a probability function, $\phi_{t}$, so the task consists of finding the rule that describes such process in time, $\left\{\phi_{t}, t \geq 0\right\}$, basically the aim is to find the probability that a region goes from one income group to another over time. Straightforwardly, is a first order autoregressive process, such that:

$\phi_{t}=T^{*}\left(\phi_{t-1}, u_{t}\right)=T_{u_{t}}^{*}\left(\phi_{t-1}\right)$

where $\mathrm{T}^{*}$ is an operator that "maps" probabilities computed in $\mathrm{t}-1$ and $u_{t}$ are random disturbances, which for convenience are included within the operator $T_{u_{t}}^{*}$. If space data of the considered economies is discretized, $T_{u_{t}}^{*}$ it becomes a transition probability matrix and if it does not change over time the expression (8) can be written as a finite homogeneous Markov chain in time:

$\phi_{t+1}=M^{\prime} \phi_{t}$

And if for all $s \geq 1$, it is truth that:

$\phi_{t+s}=\left(M^{s}\right)^{\prime} \phi_{t}$

The limit of this equation is the ergodic distribution, i.e., the distribution behavior in the long term. Since no optimal method to define groups or states in the transition matrix exists, ultimately the choice depends on the researcher's selections.

\section{SOME STYLIZED FACTS OF THE ZMCM}

The Mexico City Metropolitan Area (Zona Metropolitana de la Ciudad de México, ZMCM) contains 76 administrative units of three Mexican states: Hidalgo, Estado de México and Distrito Federal (Figure 1). It includes 16 boroughs and 60 municipalities and account for only $0.4 \%$ of the country's area. In this metropolitan area, the most populous municipalities in the country are located, Iztapalapa in the Distrito Federal and Ecatepec de Morelos in the Estado de México. Furthermore, this metropolitan area is composed of the most dynamic peripheral municipalities regarding population growth (CONAPO 2005) as Chicoloapan, Tecámac, Huehuetoca, Cuautitlán, Ixtapaluca and Tezoyuca in the Estado de México recorded growth rates above five 


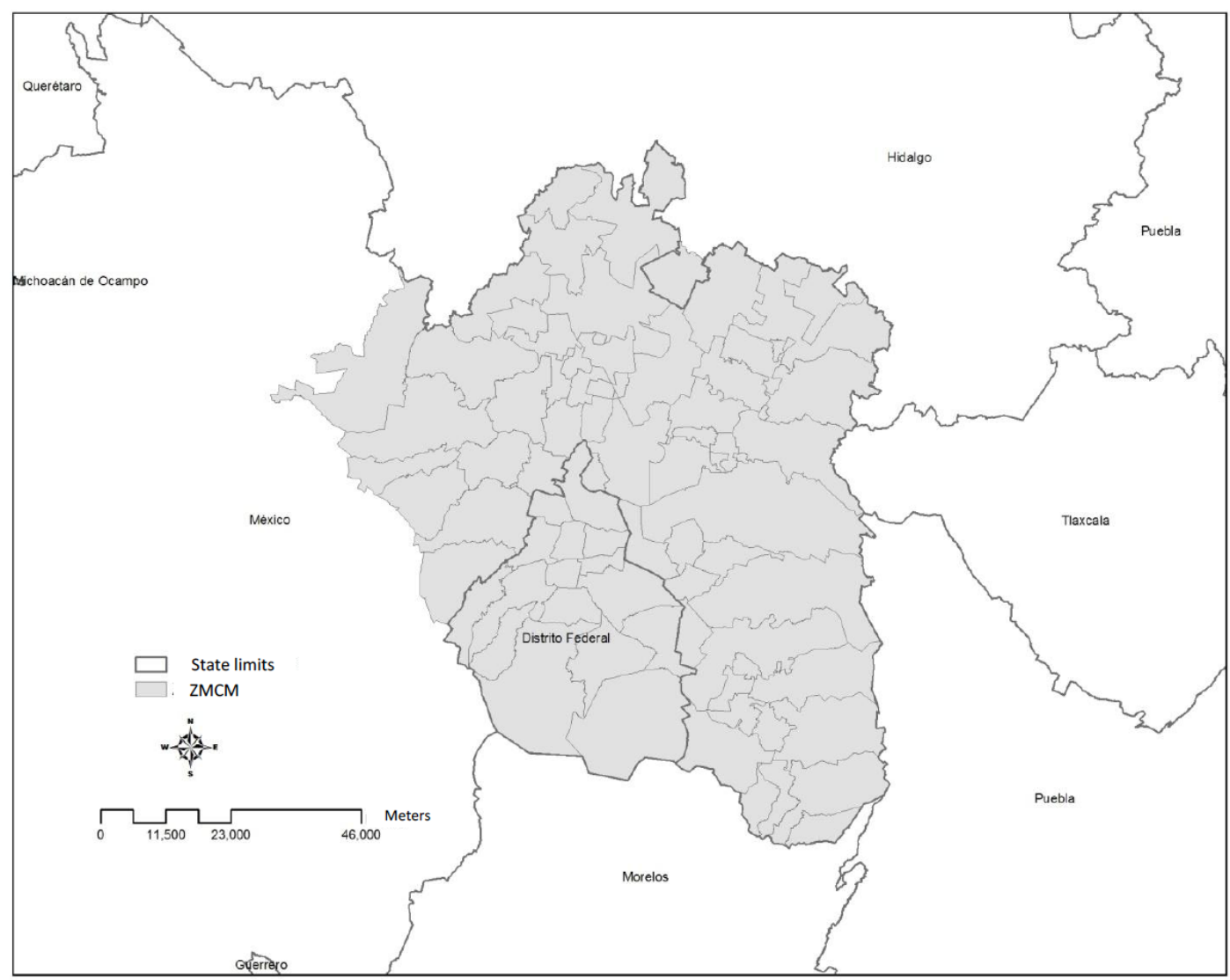

Figure 1: Mexico City Metropolitan Area.

Source: Authors' calculations based on INEGI-Marco geoestadístico nacional.

Table 1: Average Annual Population Growth Rate of the ZMCM

\begin{tabular}{|c|c|c|c|c|}
\hline Territorial area & $\mathbf{1 9 9 0 - 1 9 9 5}$ & $\mathbf{1 9 9 5 - 2 0 0 0}$ & $\mathbf{2 0 0 0 - 2 0 0 5}$ & $\mathbf{2 0 0 5 - 2 0 1 0}$ \\
\hline \hline ZMCM & 2.13 & 1.24 & 0.9 & 0.9 \\
\hline Nacional & 1.78 & 1.42 & 1.09 & 0.84 \\
\hline
\end{tabular}

Source: Author's calculations based on German-Soto (2014), CONAPO and Censos de población y vivienda, INEGI.

percentage points between 2000 and 2005. The behavior of the population growth in ZMCM since 1990 appears in Table 1, which highlights the slowdown occurred in the 1990-1995 and 1995-2000 quinquenniums and the stabilization during the last two periods: $2000-2005$ and 2005-2010.

About one-fifth of the total national population lives in the area considered, as shown in Table 2. The behavior within the administrative units of the metropolitan area is varied, as shown in Tables $\mathbf{3}$ and 4, which present the five municipalities with highest population growth and greatest population share, respectively. The average growth rate for the period for these municipalities is more than five percentage points between 1990-2010 while the most dynamic period is the last five years, 2005 to 2010. The highest population share of the metropolitan area are in Iztapalapa and Ecatepec de Morelos, which together account for nearly one-fifth of the total population of the study area in 2010.

In economic terms, the metropolitan area generated close to a quarter of the national value added in 2008, although its share has been falling for more than a decade ago, it is still considerable (Table 5). Essentially half of the value added in the services sectors nationally is produced in the ZMCM. The weight of the secondary sector has dropped significantly in a decade, from representing roughly a fifth of national production in 1998 to barely exceeds one-tenth of the production in this sector in 2008 . The employment to 
Table 2: Percent of National Population in the ZMCM

\begin{tabular}{|c|c|c|c|c|c|}
\hline Territorial area & 1990 & 1995 & 2000 & 2005 & 2010 \\
\hline ZMCM & 18.53 & 18.86 & 18.69 & 18.51 & 18.56 \\
\hline Estado de México & 12.13 & 12.63 & 13.08 & 13.48 & 13.87 \\
\hline Distrito Federal & 10 & 9.31 & 8.83 & 8.48 & 8.16 \\
\hline Hidalgo & 2.33 & 2.34 & 2.32 & 2.28 & 2.25 \\
\hline
\end{tabular}

Source: authors' own calculations based on CONAPO and Censos de población y vivienda, INEGI.

Table 3: Municipalities with Highest Population Growth Rate in the ZMCM, Percentage

\begin{tabular}{|c|c|c|c|c|c|}
\hline Borough/municipality & 1990-1995 & $1995-2000$ & $2000-2005$ & $2005-2010$ & $1990-2010$ \\
\hline Huehuetoca & 5.09 & 3.29 & 9.2 & 10.87 & 7.07 \\
\hline Ixtapaluca & 6.44 & 9.66 & 7.59 & 1.73 & 6.31 \\
\hline Tizayuca & 5.37 & 3.32 & 4.07 & 11.49 & 6.02 \\
\hline Nextlalpan & 6.79 & 5.35 & 2.88 & 8.84 & 5.94 \\
\hline Acolman & 4.71 & 2.37 & 4.69 & 12.13 & 5.91 \\
\hline
\end{tabular}

Source: authors' own calculations based on CONAPO and Censos de población y vivienda, INEGI.

population ratio in this metropolitan area on the national total is about a quarter for all years listed in the next table.

The predominantly urban municipalities and boroughs that compose the ZMCM explain why the primary sector shows acute declines in employment and value added, the truly surprising fact is the decrease in the production value of the agricultural sector nationally (Table 7).

In the period 2003-2008 occurs the worst performance regarding value creation for the ZMCM: the secondary sector practically stagnated, while the primary and tertiary experienced negative ratesof growth. Despite the decrease in value creation in the

Table 4: Municipalities and Boroughs with Highest Share of Population in the ZMCM, Percentage

\begin{tabular}{|c|c|c|c|c|c|}
\hline Borough/municipality & $\mathbf{1 9 9 0}$ & $\mathbf{1 9 9 5}$ & $\mathbf{2 0 0 0}$ & $\mathbf{2 0 0 5}$ & $\mathbf{2 0 1 0}$ \\
\hline \hline Iztapalapa & 9.58 & 9.81 & 9.64 & 9.46 & 8.03 \\
\hline Ecatepec de Morelos & 7.83 & 8.42 & 8.82 & 6.77 & 6.2 \\
\hline Gustavo A. Madero & 8.15 & 7.27 & 6.72 & 5.93 & 5.52 \\
\hline Nezahualcóyotl & 8.07 & 7.13 & 6.66 & 4.27 & 4.14 \\
\hline
\end{tabular}

Source: authors' own calculations based on CONAPO and Censos de población y vivienda.

Table 5: Percentage of Total National Value Added and Employment by Sector

\begin{tabular}{|c|c|c|c|c|c|c|}
\hline \multirow{2}{*}{ Sector } & \multicolumn{2}{|c|}{1998} & \multicolumn{2}{|c|}{2003} & \multicolumn{2}{|c|}{2008} \\
\hline & Employment & Value added & Employment & Value added & Employment & Value added \\
\hline Primary & 0.34 & 0.4 & 0.27 & 0.07 & 0.12 & 0.02 \\
\hline Secondary & 21.5 & 19.39 & 18.91 & 13.56 & 16.78 & 10.23 \\
\hline Tertiary & 29.15 & 47.97 & 27.98 & 48.76 & 26.61 & 46.5 \\
\hline Total & 25.95 & 35.36 & 24.74 & 31.14 & 23.57 & 24.03 \\
\hline
\end{tabular}

Source: Authors' calculations based on Censos Económicos 1999-2009. 
Table 6: Average Value Added and Employment Growth Rate, ZMCM

\begin{tabular}{|c|c|c|c|c|c|c|}
\hline \multirow{2}{*}{ Sector } & \multicolumn{2}{|c|}{$1998-2003$} & \multicolumn{2}{c|}{ 2003-2008 } & \multicolumn{2}{c|}{$1998-2008$} \\
\cline { 2 - 7 } & Employment & Value added & Employment & Value added & Employment & Value added \\
\hline \hline Primary & -1.8 & -35.26 & -16.39 & -23.05 & -9.39 & -29.42 \\
\hline Secondary & -2.29 & 1.89 & -0.38 & 0.05 & -1.34 & 0.97 \\
\hline Tertiary & 4.09 & 4.3 & 4.47 & -4.89 & 4.28 & -0.4 \\
\hline Total & 2.29 & 3.75 & 3.37 & -3.73 & 2.83 & -0.06 \\
\hline
\end{tabular}

Source: Authors' calculations based on Censos Económicos 1999-2009.

Table 7: Average Value Added and Employment Growth Rate, Total Economy

\begin{tabular}{|c|c|c|c|c|c|c|}
\hline \multirow{2}{*}{ Sector } & \multicolumn{2}{|c|}{$1998-2003$} & \multicolumn{2}{c|}{ 2003-2008 } & \multicolumn{2}{c|}{$1998-2008$} \\
\cline { 2 - 7 } & Employment & Value added & Employment & Value added & Employment & Value added \\
\hline \hline Primary & 2.45 & -8.65 & -1.73 & -2.68 & 0.34 & -5.71 \\
\hline Secondary & 0.25 & 9.44 & 2.03 & 5.86 & -3.14 & 5.23 \\
\hline Tertiary & 4.94 & 3.96 & 5.52 & 1.39 & 3.63 & -0.09 \\
\hline Total & 3.27 & 6.42 & 4.38 & & 3.87 \\
\hline
\end{tabular}

Source: Authors' calculations based on Censos Económicos 1999-2009.

tertiary sector, employment grew substantially, more than four percentage points. The growth of employment at the national level in the services sector between 1998-2008 is indeed even higher than that of the ZMCM while the period of 2003-2008, the national figures underwent a decrease similar to the one that was observed in the Metropolitan area. In short, the tertiary sector employs more people, but this addition of personnel does not contribute to raising the value added, measured in real terms.

The secondary sector has the opposite behavior: valued added generated in the metropolitan area during the period 1998-2008 increased at an average annual rate of almost one percentage point, whereas employment decreased at a rate of $1.3 \%$ annually, which could represent a shift in the labor force from the secondary (industrial) sector to the services sector, in some sort of outsourcing but in a precarious way. Nationally, in the decade 1998-2008, the secondary sector was the most dynamic as it reached an average annual growth rate of more than seven and a half percentage points, nearly double the economy growth as a whole. Nevertheless, employment growth in this sector amounts to only $20 \%$ of the services sector. The decline in the employment share of the secondary sector in the examined area is an evidence of the productive hollowing already referred.

A trend of workers being thrown out from the secondary sector into services in the study area is evident when we look at the sectoral structure of the metropolitan area. The share of the services sector is significantly higher, accounting for two-thirds of the people employed in 1998 to almost four-fifths in 2008, whereas the share of value added is continuously close to $75 \%$ each year. Nationally, this has not happened, rather the ratio of the output produced by industrial activities has increased to more than half the value added in 2008; if we examine the share of people employed in this sector nationally it may be noticed a steady reduction in the weight of the employment created by industry, exactly opposite to the services sector performance, which accounts for over two thirds of people employed in 2008.

Nationwide, the relative importance of the ZMCM in output has decreased. Likewise, it also exhibits a lower dynamics of growth between 1998-2008 compared to the total national economy, only the services sector seems to approach the dynamics of domestic growth, albeit only in regards to job creation. On the other hand, some employment has moved from the secondary sector to the tertiary without the increase of the value yielded by the latter considerably at both national and metropolitan level, allowing us to venture the hypothesis that the service sector serves as an outlet for the shortage of jobs in the industrial economy.

\section{EMPIRICAL RESULTS AND DISCUSSION}

The calculation of inequality and polarization measures proposed by Ezcurra and Rodríguez-Pose 


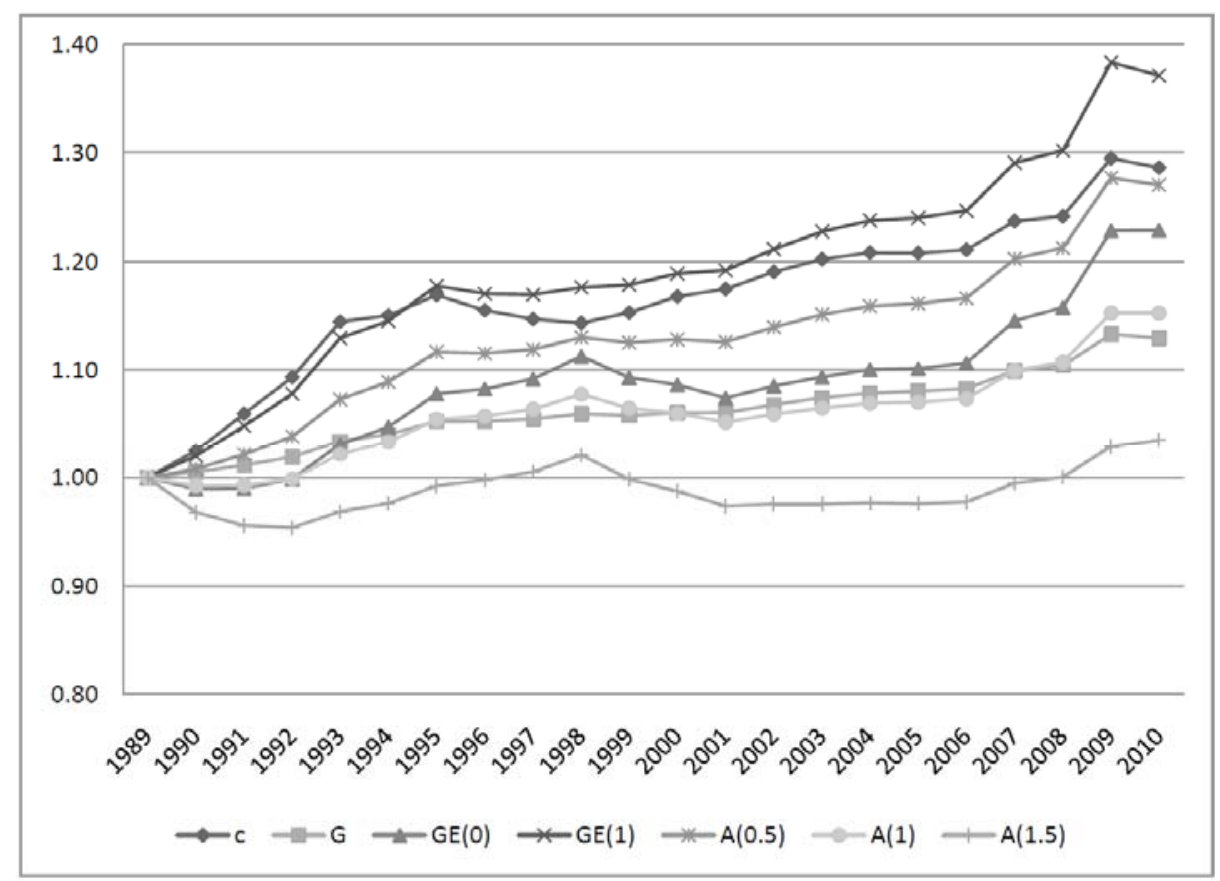

Figure 2: Inequality measures of gross domestic product per capita of the ZMCM, 1989-2010. (1989=1.0).

Source: authors' own calculations based on Mendoza (2013), German-Soto (2005) and Censos de población y vivienda.

(2009) for the local environment of the ZMCM was conducted using the statistical package DASP for STATA developed by Araar and Duclos (2007). The measure of income in the territory is the gross domestic product per capita in 1989-2010. ${ }^{2}$ Estimates for the total municipal population were performed using interpolation and projections based on information from CONAPO and the Censo de Población y Vivienda 2010.

\section{i. Specific Measures of Inequality}

In the case of entropy, we follow Ezcurra and Rodriguez-Pose remarks and allow $\theta$ to assume only the values of 0 and 1 ; while for $\varepsilon$ in the Atkinson index we use the values $0.5,1.0$ and 1.5 . The results of this set of indices are presented in Figure 2. It is clear that regardless of the index used, inequality has increased in ZMCM at the end of the period considered: in 2010 all indices are above their initial values in 1989. But it is possible to acknowledge at least three distinct trends in

\footnotetext{
${ }^{2}$ The lack of official GDP figures for municipalities in Mexico, was overcome by the use of some estimates. Briefly, the methodology used for constructing the missing data considered: 1) Implementation of lineal interpolation methods using Gross Value Added of Economic Census (1994, 1998, 2004 and 2008) at municipality level from Federal District, Mexican and Hidalgo states, to estimate distributional series during the period 1994-2010. 2) Estimations from (1) were applied to the GDP State series estimations of German-Soto (2005 y 2015) to obtain GDP at municipality level that are equivalent to the GDP series at state level of German-Soto (2005 y 2015). A complete discussion of the methods and their limits can be found in Mendoza (2013:143-176).
}

the behavior of these indexes. The first period runs from 1989 to 1995 in which inequality reveals a growing and accelerated behavior as shown by $c, G$ (1), $A(0.5)$ and to a lesser degree $G$. On the other hand, $G(0), A(1)$ and $A$ (1.5) show a reduction in inequality at the beginning of this sub-period, but from 1992 this behavior starts a U-turn.

The second sub period runs from 1995 to 2006. Inequality continues to increase but at a slower rate, and in some moments it seemed to decrease $(G(0), A$ (1.5)). From 2006 to 2009 occurred again a discernible trend change in which all indexes without exception exhibit an increase in inequality. Our study period concludes with a minor reduction between 2009 and 2010 , albeit clearly over the levels of 1989 . Therefore, it is possible to state the intra-regional inequality level has increased among municipalities and boroughs in the ZMCM between 1989-2010. This increment (if we do not consider the values of the most volatile indexes, $A(1.5)$ and $G E(1))$ moves between 13\% (Gini index) and $29 \%$ (coefficient of variation).

\section{ii. DER Polarization Index}

It has been pointed out that a decreasing inequality in per capita income of municipalities is compatible with increasing polarization, as the levels of per capita income can be concentrated around two or more average distribution behaviors, resulting in a decrease 


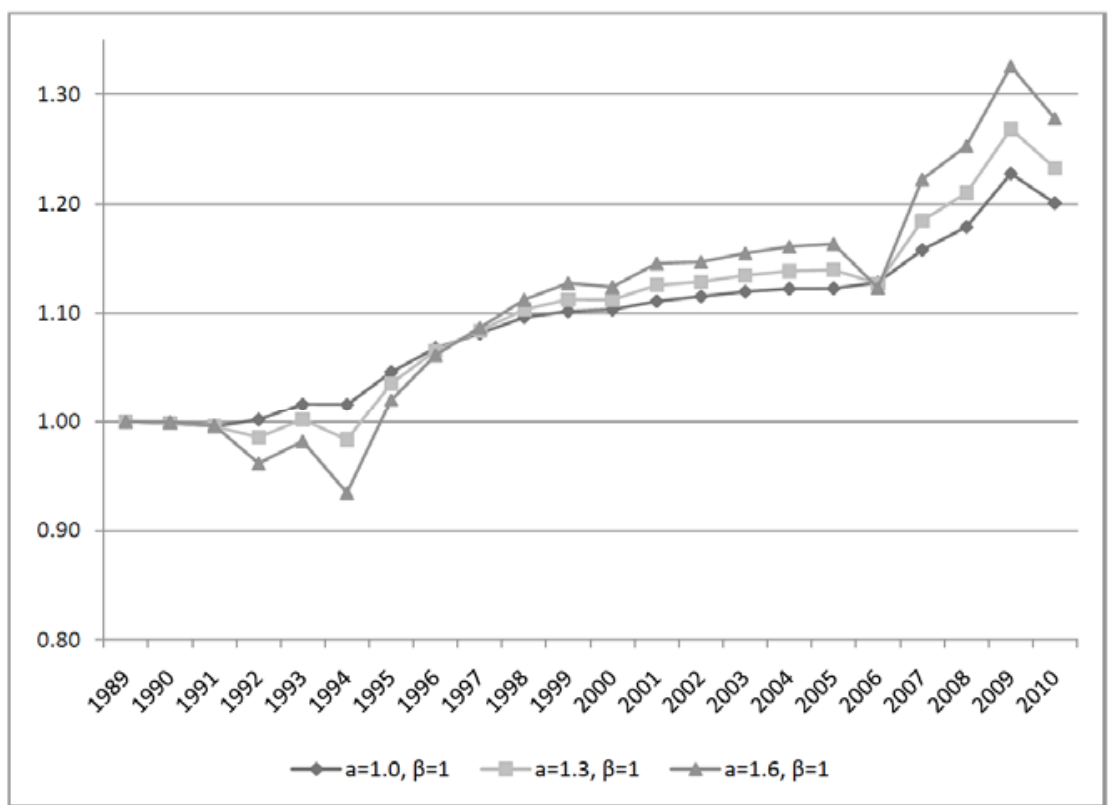

Figure 3: Polarization in the ZMCM, two groups $(1989=1.0)$.

Source: authors' calculations based on Mendoza (2013), German-Soto (2005) and Censos de población y vivienda.

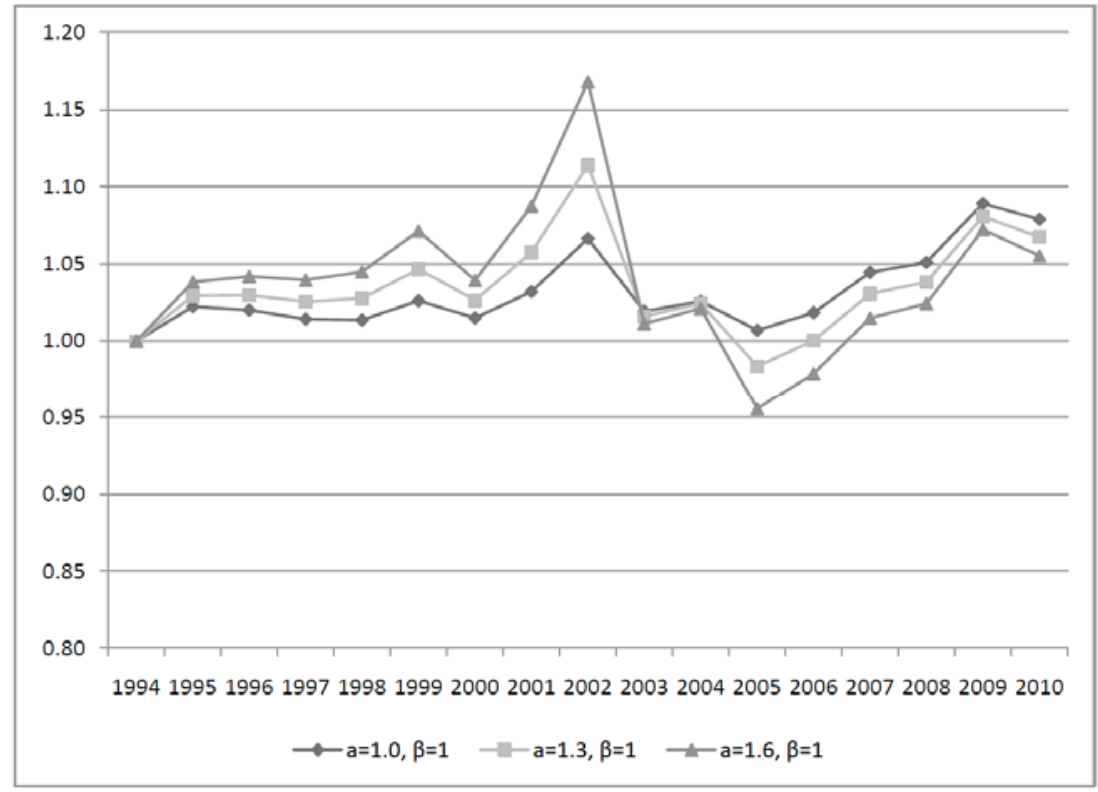

Figure 4: Polarization in the ZMCM, three groups $(1989=1.0)$.

Source: authors' calculations based on Mendoza (2013), German-Soto (2005) and Censos de población y vivienda.

in dispersion with greater polarization (Quah 1994). To capture the existence of this possible effect, the data set used is partitioned into groups ${ }^{3}$. In this paper, the level of per capita gross domestic product was partitioned into two and three groups. Thus, for each

${ }^{3}$ The groups are obtained with the algorithm proposed by Davies and Shorrocks (1989), which permits to find the optimal partition of the distribution that minimizes the error term, i.e., minimizes the Gini index value among the formed groups. partition, alpha assumed values of 1.0, 1.3 and 1.6, whereas the parameter beta was kept fixed and equal to unity. The results are shown in Figures $\mathbf{3}$ and $\mathbf{4}$.

When considering the case of partition into two groups (Figure 3, bi-polarization) an increase around 20 to $28 \%$ in 2010 of the differences between groups is observed depending on the values taken by alpha. Similar to the case of the specific inequality measures, three sub-periods are observed: 1989-1995, 1995-2006 
and 2006-2010. In the first period, polarity increases although in some years it fluctuates according to two of the estimates, and it could even be said that it decreases, through 1995-2006 displays a conspicuous increase, albeit at a moderate pace. In the last subperiod and until 2009, the level of polarization between the two groups increased rapidly: between 10\% and $20 \%$ in just three years.
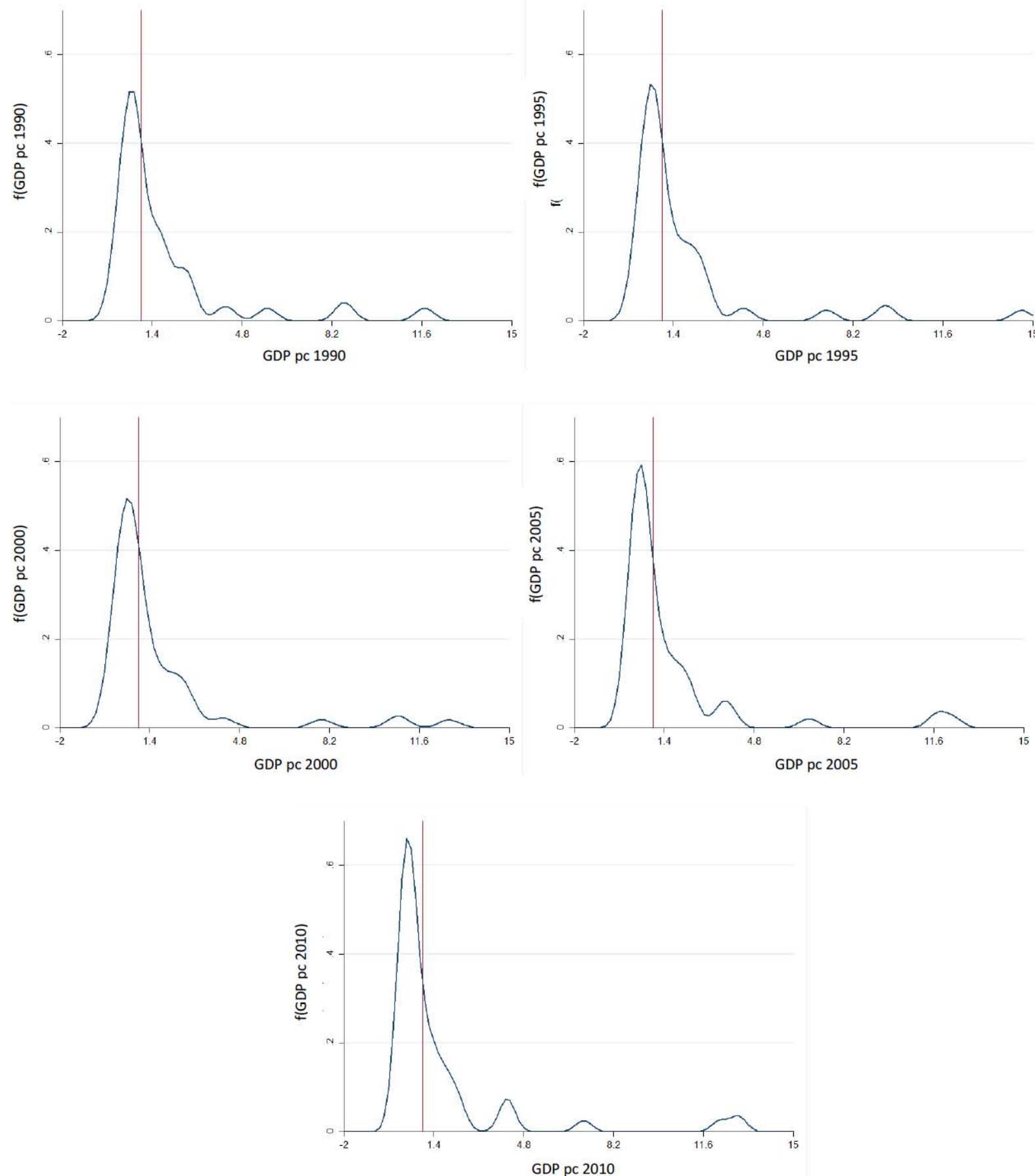

Figure 5: Kernel density functions of GDP per capita from the municipalities and boroughs of the ZMCM (bandwidth, $h$, according to Silverman, 1986).

Source: authors' calculations based on Mendoza (2013), German-Soto (2005) and Censos de población y vivienda.

\section{iii. Non-Parametric Methods to Estimate Polarization}

We studied the so-called external shape of the distribution by calculating stochastic kernels of the per capita gross domestic product of municipalities and boroughs of ZMCM. The bandwidth or smoothing parameter $(h)$ of the kernel distribution function used

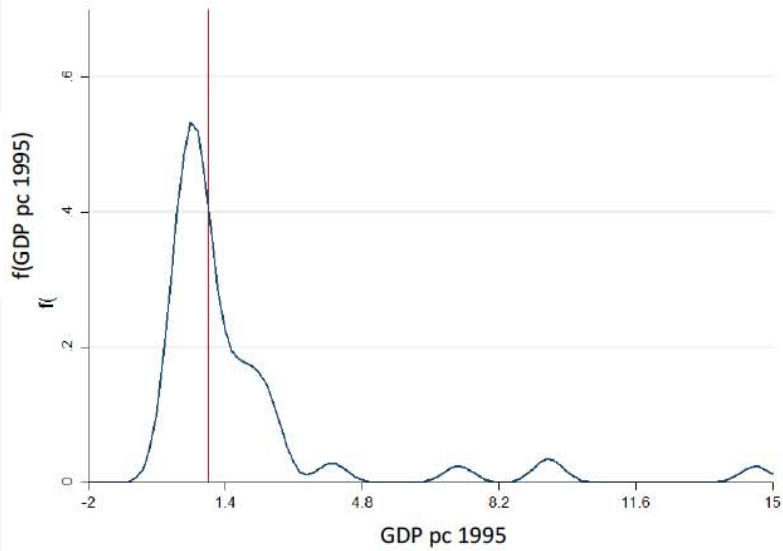


here is optimal, according to Silverman (1986). Distribution functions are shown in Figure $\mathbf{5}$.

Additionally, we describe the inside distribution dynamics that seeks to determine the persistence over time of the relative position of all municipalities and boroughs in a particular income group. We considered two versions of analysis; the first is a "traditional" perspective that presents a three-dimensional joint distribution graph of GDP per capita for two periods, 1990 and 2010 (Figure 6), and the respective curve levels (Figure 7). The second version of inside distribution analysis uses graphical instruments proposed by Hyndman et al. (1996), Hyndman (1996), and are resume by Basile (2007), these instruments are the Stacked Conditional Density Plot graphs, corresponding to Figure 8, and Highest Conditional Density Region graph (HDR), shown in Figure 9.

Figure 5 displays the density functions of GDP per capita for the municipalities and boroughs of the metropolitan area in five-year periods from 1990 to 2010 and exhibits the external shape of the distribution. The vertical line that crosses the unit value on the abscissa indicates the average per capita GDP of the entire ZMCM: if the greatest "mass" of the density function is located around the average value it would indicate that most municipalities and boroughs of the metropolitan area have a per capita income close to the whole metropolitan zone. Nevertheless, this is not

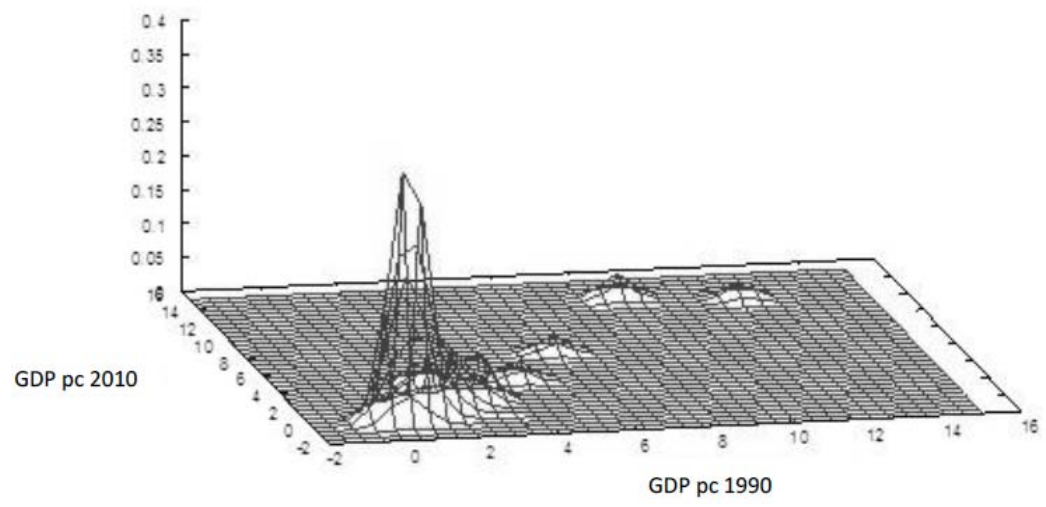

Figure 6: Joint distribution of the GDP per capita kernel density of the ZMCM, 1990-2010.

Source: authors' calculations based on Mendoza (2013), German-Soto (2005) and Censos de población y vivienda.

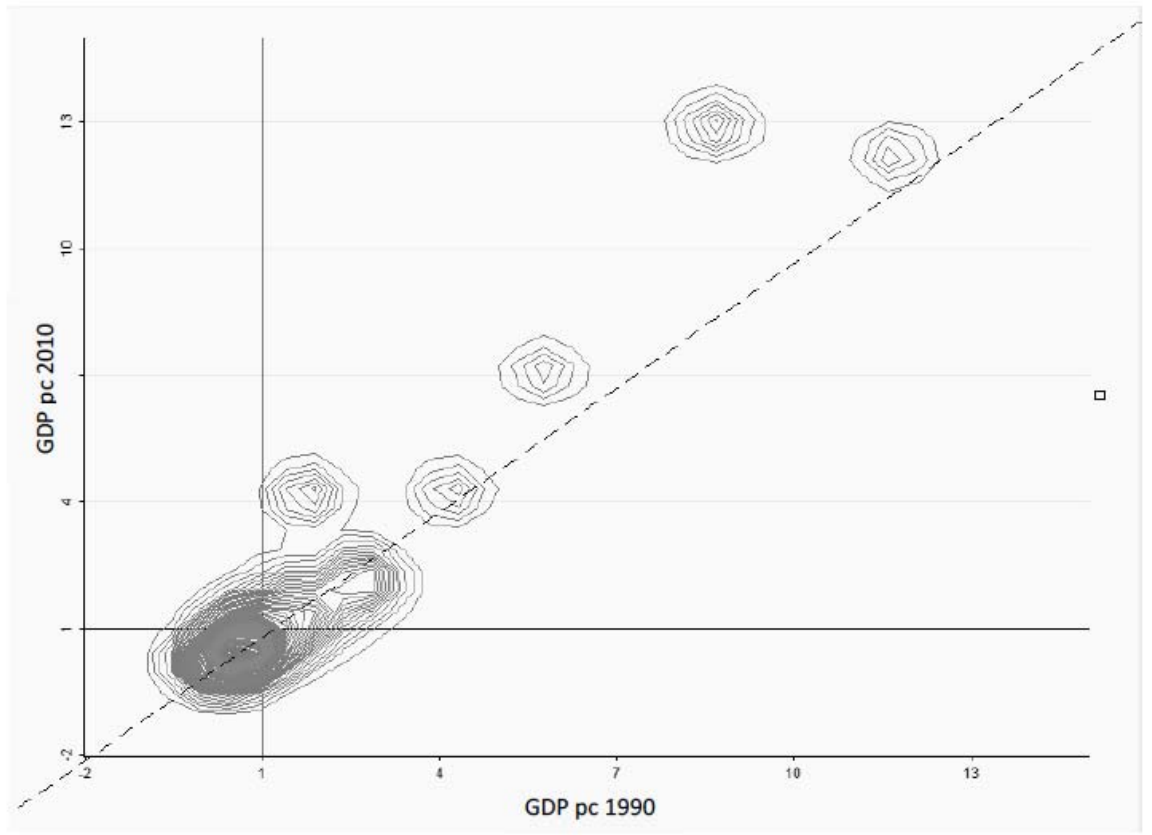

Figure 7: Level curves of the joint distribution of the GDP per capita kernel density of the ZMCM, 1990-2010. Source: authors' calculations based on Mendoza (2013), German-Soto (2005) and Censos de población y vivienda. 
the case because for each of the cuts, most municipalities and boroughs exhibited a per capita income lower than the overall average.

Figure 5 also exhibits a number of municipalities and boroughs with per capita income three to ten times higher than the metropolitan area average. Moreover, there is a sub-group whose income value was around 4.2 times the metropolitan average circa 2010. Changes in the shape of the distribution further indicate a gradual increase in the number of municipalities and boroughs possessing per capita income below the average, particularly from 2000 to 2010 .

Figure 6 exhibits the joint distribution of the GDP per capita kernel density of the ZMCM from 1990 to 2010 in a three-dimensional perspective, while Figure 7 shows the level curves of the first, taken together constitute the traditional analysis of the dynamics of income distribution. Figure 7 reveals a divergent pattern in middle and high income once, in the period studied, part of the "mass" turns in an anti-clockwise direction, whereas municipalities and boroughs closer to the mean seem to remain unchanged. This graph also shows that most municipalities and boroughs cluster at an income level inferior to the study area average income.

Figures 8 and $\mathbf{9}$ are the alternative form of dynamic transition analysis discussed by Basile (2007), of which for purposes of convergence analysis the HDR graph is extremely important. The Stacked Conditional Density graph (Figure 8) displays 76 conditional densities plotted next to each other in perspective; this graphic resource allows to observe changes in the shape of the variable distribution at the period $t+\mathrm{T}$ (2010) over the range of the same variable in period $t$ (1990). Each univariate density plot describes the transition of the variable at the time $\mathrm{t}+\mathrm{T}$ given its value at time $t$, yielding more information than the traditional approach as it puts emphasis on conditioning the probabilities.

In the Highest Conditional Density Regions graph (Figure 9), each upright bands represents a projection in the Cartesian plane of the conditional density of $y$ on $x$. In each of the bands it is shown the $25 \%$ (darker area), $50 \%, 75 \%$ and $90 \%$ (lighter area) of regions with a higher conditional density (HDRs). A High Density Region (HDR) is the smallest region of the sample containing a given probability (Basile 2007) In the case of a unimodal distribution, HDRs are exactly typical probabilities around the average value; however, in case of a multimodal distribution, the graph will display multiple discontinuous sub-regions.

A 45-degree line divides the graph; if the values 25 to $50 \%$ of HDRs are crossed by this diagonal it means that most of the elements of the distribution remain at time $\mathrm{t}+\mathrm{T}$ in the place where they were in the period $t$

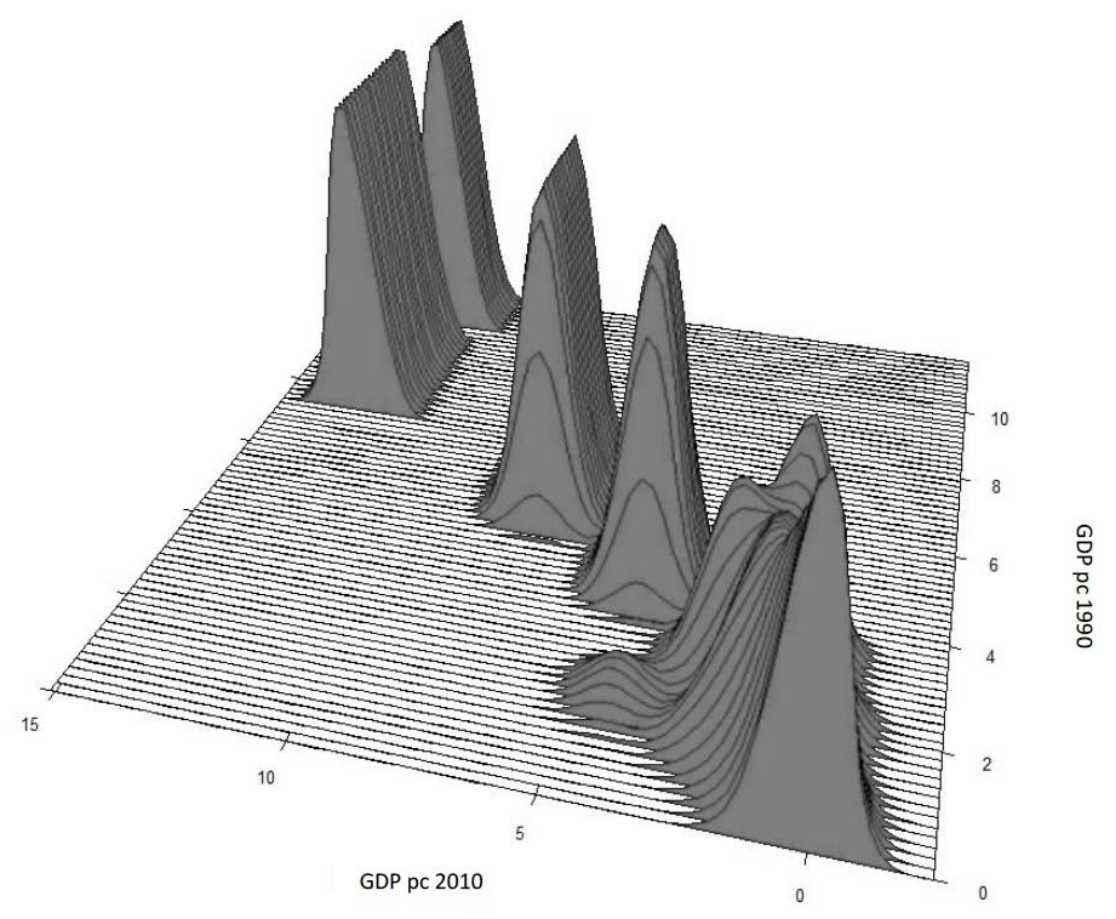

Figure 8: Cumulative conditional density of the income per capita of the ZMCM, 1990-2010 (Stacked density plot). Source: authors' calculations based on Mendoza (2013), German-Soto (2005) and Censos de población y vivienda. 


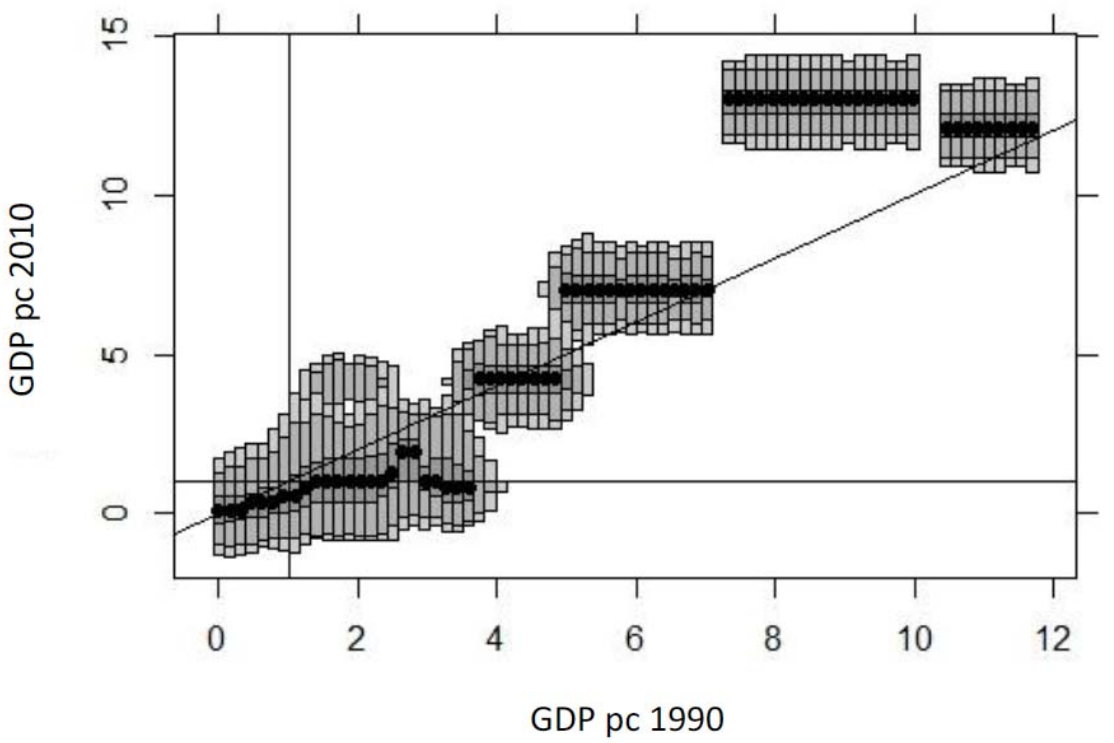

Figure 9: High density regions of the income per capita conditional distribution of the ZMCM, $1990-2010$ (HDR plot).

Source: authors' own calculations based on Mendoza (2013), German-Soto (2005) and Censos de población y vivienda.

and, therefore, exists a strong persistence. If the 45degree line only crosses the HDRs in their $75-90 \%$ values, exists a weak persistence.

A horizontal line intersecting the ordinate axis at zero and crossing all HDRs in the range 25-50\% defines a strong global convergence towards equal distribution, while a line crossing all HDRs between values $70-90 \%$ defines a weak global convergence. On the other hand, if some HDRs are crossed by a horizontal line of any value in their ranges of $25-50 \%$ a strong local convergence or clubs happens, and it will be a weak local convergence if such line crosses the HDRs in the range of $70-90 \%$. The modes of each distribution of the HDRs are shown as dark spots on the graph.

HDR graph reveals a strong persistence in low income levels (HDR as up to 3 times the average income of the ZMCM are crossed in the areas of 25 or $50 \%$ ). There is no evidence of any sort of global convergence among municipalities and boroughs of the ZMCM. Nonetheless, information extracted from graphical analysis displays local convergence process or clubs.

At least four clubs can be distinguished. A first club of strong convergence around the metropolitan area average, a second group formed around the value of four times the metropolitan average (as observed in the cross-section kernel plots), a third group made up of the municipalities and boroughs with values close to seven times the average of the area studied and a last club located about 13 times the metropolitan average. The largest of them is the one that revolves around the mean value. Regardless of that, it cannot be affirmed that municipalities and boroughs possessing a per capita income lower than the metropolitan average may improve in the next 20 years (since not all HDRS of these low-income groups are above the main diagonal).

To sum up, all the measures estimated here show that inequality has increased within municipalities and boroughs in the ZMCM. Inequality has moved alongside an increment of polarization as indicated not only by the EGR index, but also by the dynamic transition analysis itself. The latter not only shows effectively a process of polarization (revealing no global convergence paths), but also it is useful to identify at least four sub-groups or convergence clubs. Finally, it is essential to stress the enormous distance between the lowest income group (less than the metropolitan average) and the highest group, which is located 10 times above average.

\section{CONCLUDING REMARKS}

By estimating several indexes it was demonstrated that inequality has increased within municipalities and boroughs of the ZMCM, and this phenomenon concurs with the increment in polarization. Through a dynamic transition analysis, it was shown that such process of polarization is characterized by the formation of four sub-groups or convergence clubs. 
All indices used reveal that inequality in the ZMCM has increased at the end of the studied period. In the period from 1989 to 2010 it is possible to notice at least three distinct trends in the behavior of the indices: from 1989 to 1995, in which inequality describes an upward behavior; a second period, from 1995 to 2006, in which inequality continues to rise but a slower pace; and a third period, from 2006 to 2009, where inequality is growing rapidly.

An increase of the polarity is observed if two groups are constructed, at the end of the period polarization increased between 20 and $28 \%$. Three sub-periods can be distinguished: 1989-1995, in which polarity increases with oscillations; 1995-2006, where polarity unquestionably rose; and 2006-2010, where polarity grew rapidly.

Analysis of the shape of the distribution reveals that most municipalities and boroughs exhibited a per capita income lower than the average, besides the difference in the income level is up to 10 times the metropolitan area average. The number of municipalities and boroughs that have per capita income below the average rose. A divergent pattern in the middle and upper income became evident and a strong persistence in low-income levels became evident, whereas we didn't find any sort of global convergence among municipalities and boroughs of the ZMCM, but instead local convergence processes or clubs, were found.

\section{ACKNOWLEDGEMENT}

This paper was written as part of the research project DGAPA-UNAM PAPIIT IN304214: Las ciudades creativas y su potencial para el desarrollo de las zonas metropolitanas en México.

\section{REFERENCES}

Araar, Abdelkrim and Jean-Yves Duclos. 2007. DASP: Distributive Analysis Stata Package. PEP, World Bank, UNDP and Université Laval.

Barro, Robert. 1991. "Economic Growth in a Cross-Section of Countries." Quarterly Journal of Economics 106: 407-43. http://dx.doi.org/10.2307/2937943

Basile, Robert. 2007. "Intra-distribution dynamics of regional percapita income in Europe: evidence from alternative conditional density estimators." Istituto Di Studi E Analisi Economica, Working paper 75.

Ben-David, Dan. 1994. "Income Disparity Among Countries and the Effects of Freer Trade." Pp. 45-64, in Economic Growth and the Structure of Long-Run Development, edited by $L$. Pasinetti and R. Solow: Macmillan.

Blanchard, Oliver and Katz Lawrence. 1992. "Regional Evolutions." Brookings Papers on Economics Activity 23: 1-76. http://dx.doi.org/10.2307/2534556
Borrayo, Rafael and Juan Manuel Castañeda. 2011. "Análisis de dinámica: Un enfoque no paramétrico aplicado a la región centro de México (1988-2003)." Problemas del Desarrollo 167 (42): 7-44.

Carlino, G. A. 1992. "Are regional per capita earnings diverging?" Business Review, Federal Reserve Bank of Philadelphia: 312.

Chávez, Ana and Julio Guadarrama. 2004. "La región central de México en transición: tendencias económicas y migratorias al final del milenio." Pp. 147-187 in Procesos metropolitanos y grandes ciudades, edited by G. Aguilar: H. Cámara de Diputados LIX Legislatura, México.

CONAPO. 2005. Delimitación de las zonas metropolitanas de México. Secretaría de Desarrollo Social. Consejo Nacional de Población/Instituto Nacional de Estadística, Geografía e Informática.

Connolly, Priscilla. 1993. "La reestructuración económica y la ciudad de México." Pp. 45-70 in Dinámica urbana y procesos sociopolíticos, lecturas de actualización sobre la ciudad de México, edited by R. Coulomb and E. Duhau. México: CENVI-UAM Azcapotzalco.

Crihfield, J. B. and M.P.H. Panggabean. 1995. "Growth and Convergence in U.S. Cities." Journal of Urban Economics 38:138-65.

http://dx.doi.org/10.1006/juec.1995.1026

Davis, J. and A. Shrrocks. 1989. "Optimal grouping of income and wealth data." Journal of Econometrics 42: 97-108. http://dx.doi.org/10.1016/0304-4076(89)90078-X

Drennan, M. P. and J. Lobo. 1999. "A Simple Test for Convergence of Metropolitan Income in the United States." Journal of Urban Economics 46: 350-359. http://dx.doi.org/10.1006/juec.1998.2126

Drennan, M. P. 1996. "The interruption of income convergence and income growth in large cities in the 1980s." Urban Studies 33(1): 63-71. http://dx.doi.org/10.1080/00420989650012121

Esteban, J. and D. Ray. 1994. "On the measurement of polarization." Econometrica 62: 819-852. http://dx.doi.org/10.2307/2951734

Ezcurra, Roberto and Andrés Rodríguez-Pose. 2009. "Measuring the regional divide." Pp. 329-353 in Handbook of regional growth and development theories, edited by $\mathrm{R}$. Capello and $\mathrm{P}$. Nijkamp. Edward Elgar Publishing. http://dx.doi.org/10.4337/9781848445987.00026

Felipe, J. and J. McCombie. 2015. The aggregate production function and the measurement of technical change 'Not even wrong'. Edward Elgar Publishing,

Galor, Oded. 1996. "Convergence? Inferences from Theoretical Models." The Economic Journal 106: 1056-69.

Garnick, D. H. 1990. "Accounting for regional differences in per capita personal income growth: an update and extension." Survey of Current Business 70: 29-40.

German-Soto, Vicente. 2005. "Generación del producto interno bruto mexicano por entidad federativa, 1940-1992." El Trimestre Económico, 72(3): 617-653.

Glaeser, E. L., J. A. Scheinkman and A. Shleifer. 1995. "Economic Growth in a Cross-Section of Cities." Journal of Monetary Economics 36:117-143. http://dx.doi.org/10.1016/0304-3932(95)01206-2

Hyndman, R. 1996. "Computing and Graphing Highest Density Regions." The American Statistician 50: 120-126.

Hyndman, R., D. Bashtannyk and G. Grunwald. 1996. "Estimating and visualizing conditional densities." Journal of Computational and Graphical Statistics 5: 315-336.

Isaac, Jorge and Luis Quintana. 2012. "Industria y vaciamiento productivo regional en México." Pp. 39-64 in Desarrollo regional y urbano, edited by José L. Calva. México: Juan Pablos. 
Krugman, P. 1991. Geography and Trade. Cambridge: MIT Press.

Lucas, Robert. 1988. "On the mechanics of economic development." Journal of Monetary Economics 22: 3-42. http://dx.doi.org/10.1016/0304-3932(88)90168-7

Maier, G. and M. Trippl. 2009. "Location/allocation of regional growth." Pp. 53-65 in Handbook of regional growth and developmente theories, edited by R. Capello and P. Nijkamp. United Kingdom: Chaltenham. http://dx.doi.org/10.4337/9781848445987.00009

Mallick, R. 1993. "Convergence of State Per Capita Incomes: An Examination of Its Sources." Growth and Change: 321-40. http://dx.doi.org/10.1111/j.1468-2257.1993.tb00129.x

Mendoza, Miguel Ángel. 2013. ¿Convergencia o divergencia económica regional? Estudios, métodos y modelos para México y República Dominicana. Tesis Doctoral. México: Facultad de Economía, UNAM. http://saree.com.mx/unam/ sites/default/files/TesisDoctorado_Mendoza_2013.pdf

Myrdal, Gunnar. 1957. Economic Theory and Under-Development Regions. London : G. Duckworth.

Pérez-Campuzano, E. 2006. "Reestructuración urbano regional y nuevos derroteros de la migración en la región centro de México. El caso de la ZMCM." Estudios Demográficos y Urbanos, El Colegio de México, A.C., Distrito Federal: 21 (002): 331-367.

Perroux, F. 1950. "Economic space: theory and applications." Quarterly Journal of Economics 64: 89-104. http://dx.doi.org/10.2307/1881960

Quah, Danny. 1993. "Empirical Cross-section Dynamics in Economic Growth." European Economic Review 37 (2-3): 426-434. http://dx.doi.org/10.1016/0014-2921(93)90031-5

Quah, Danny. 1996a. "Regional Convergence Clusters Across Europe." European Economic Review 40(3-5): 951-958. http://dx.doi.org/10.1016/0014-2921(95)00105-0

Quah, Danny. 1996b. "Empirics for Economic Growth and Convergence." European Economic Review 40(6):13531375. http://dx.doi.org/10.1016/0014-2921(95)00051-8
Quah, Danny. 1997. "Empirics for Growth and Distribution: stratification, polarization and convergence clubs." Journal of Economic Growth 2: 27-59. http://dx.doi.org/10.1023/A:1009781613339

Romer, Paul. 1990. "Endogenous technological change." Journal of political Economy 98(5): S71-S102. http://dx.doi.org/10.1086/261725

Rosende, F. 2000. "Teoría de Crecimiento Económico: Un debate inconcluso." Estudios de Economía 27(1): 95-122.

Sala-i-Martin, Xavier. 1996. "Regional cohesion: evidence and theories of regional growth and convergence." European Economic Review 40(6): 1325-1352. http://dx.doi.org/10.1016/0014-2921(95)00029-1

Sánchez, I. 2009. "Teorías del crecimiento económico y divergencia regional en México." Entelequia 9: 129-149.

Silverman, B. W. 1986. Density estimation for statistics and data analysis. Boca Raton: CRC Press. http://dx.doi.org/10.1007/978-1-4899-3324-9

Solow M., Robert. 1956. "A Contribution to the Theory of Economic Growth." The Quarterly Journal of Economics 70(1): 65-94. http://dx.doi.org/10.2307/1884513

Unikel, L., C. Ruiz and G. Garza. 1976. El desarrollo urbano de México: diagnóstico e implicaciones futuras. México: CEED, El Colegio de México.

Valdivia, Marcos. 2008. "Desigualdad regional en el centro de México. Una exploración espacial de la productividad en el nivel municipal durante el período 1988-2003." Investigaciones Regionales 13: 5-34.

Vohra, R. 1996. "How fast do we grow?" Growth and Change 27: 4754. http://dx.doi.org/10.1111/j.1468-2257.1996.tb00895.x

Received on 08-03-2016

Accepted on 05-04-2016

Published on 06-05-2016

\section{DOI: http://dx.doi.org/10.6000/1929-7092.2016.05.07}

(C) 2016 Quintana-Romero et al.; Licensee Lifescience Global.

This is an open access article licensed under the terms of the Creative Commons Attribution Non-Commercial License (http://creativecommons.org/licenses/by-nc/3.0/) which permits unrestricted, non-commercial use, distribution and reproduction in any medium, provided the work is properly cited. 